\title{
Innovative approaches for the analysis and decontamination of mycotoxins from feed and milk
}

\author{
ADINA-MIRELA ARITON ${ }^{1}$, SORIN SERGIU CHELMU ${ }^{2 *}$ ANDRA-SABINA \\ NECULAI-VALEANU ${ }^{1}$, ALINA NARCISA POSTOLACHE ${ }^{1}$, ELENA UNGUREANU ${ }^{3}$, \\ ŞTEOFIL CREANGĂ ${ }^{1,3}$
}

${ }^{1}$ Cattle Breeding Research Station from DANCU, Iaşi; Iaşi - Ungheni road No. 9, Iaşi, 707252, Romania

${ }^{2}$ Bioterra University Bucharest; Faculty of Agrotourism Management, 81 Gârlei Street, 1st District, Bucharest, Romania

"Ion Ionescu de la Brad" University of Agricultural Sciences and Veterinary Medicine, Faculty of Horticulture, 3 Mihail Sadoveanu Alley, Iaşi, 700490 Iasi, Romania

\begin{abstract}
Mycotoxins are secondary toxic metabolites produced by some filamentous fungi. In spite of great efforts to prevent it, contamination of animal feed with mycotoxins still occurs very frequently, causing serious diseases in farm animals. Such small chemicals pose a high challenge to food safety and a serious risk to human and animal health, additionally leading to the agricultural industry's massive economic losses. They can reach our food chain either directly from plant-based food components contaminated with mycotoxins or indirectly through food-borne contamination. Aside from the concerns about the adverse effects of direct intake of mycotoxin-contaminated foods and feeds, there is also a public health concern regarding the possible ingestion of food products derived from animals, such as beef, milk or eggs containing mycotoxin residues or metabolites. Despite the constant advancement of conventional methods, current trends in science are searching for innovative solutions, thus researchers prioritize the production of detoxification technologies for highrisk resources. Nanotechnology approaches seem a promising, efficient, and low-cost way to minimize mycotoxin's health effects. This study provides new insights into potential future work that may address the difficulties of using nanotechnology to remove mycotoxins from agricultural products, in general and in the animal husbandry sector in particular.
\end{abstract}

Keywords Mycotoxins, milk, feed, decontamination, innovative techniques.

To cite this article: ARITON A-M, CHELMU SS, NECULAI-VALEANU A-S, POSTOLACHE AN, UNGUREANU E, CREANGĂ Ș. Innovative approaches for the analysis and decontamination of mycotoxins from feed and milk. Rom Biotechnol Lett. 2020; 25(1): 1304-1310. DOI: $10.25083 / \mathrm{rbl} / 25.1 / 1304.1310$

*Corresponding author: SORIN SERGIU CHELMU, Professor Doctor, Bioterra University Bucharest; Faculty of Agrotourism Management, 81 Gârlei Street, 1st District, Bucharest, Romania E-mail: sschelmu@gmail.com ; Telephone: 0744588911

First author: ADINA-MIRELA ARITON, E-mail: amariton@yahoo.ro 


\section{Introduction}

Mycotoxins are a group of secondary metabolites that are secreted by fungal organisms of the Aspergillus, Fusarium, Alternaria and Penicillium genera (OGUNADE et al, 2018). These molds generate different kinds of mycotoxins, such as aflatoxins (AFs), deoxynivalenol (DON), zearalenone (ZEA), fumonisin B1 (FB1), ochratoxin A (OTA) and citrinine (CIT), almost all being poisonous to animals (BECKER-ALGERI et al, 2016; WOMACK et al, 2016).

Mycotoxins are unpredictable and inevitable contaminants in foods and feeds around the globe. These tiny chemicals pose an open threat to food security and a severe threat to human and animal health, additionally contributing to the huge financial losses of the agricultural industry. Enormous efforts have been made to control or minimize mycotoxin in foods from around the world, but contamination of foods with mycotoxin remains a problem (ALSHANNAQ and YU, 2017).

Inadequate harvesting technologies, unsuitable processing, storage, packaging and transport conditions may increase the risk of mycotoxin production (BHAT et al, 2010).

Mycotoxins are found in a variety of animal feeds including concentrates, green forests, hay and silages (OGUNADE et al, 2017). Naturally, there are more than 400 mycotoxins, but only a few have been widely studied (NJUMBE et al, 2015). Trichothecenes, fumonisins, aflatoxins, ZEA, mycophenolic acid and roquefortine $\mathrm{C}$ are commonly found in ensiled forages (DRIEHUIS et al, 2008). The most powerful mycotoxins are aflatoxin, vomitoxin, ochratoxin, zearaleone, fumonisin, and T-2 due to their high toxicity and occurrence. They cause significant economic losses in livestock due to reduced productivity, enhanced disease incidence, chronic damage to vital organs and decreased reproductive effectiveness (IHESHIULOR et al, 2011; OGUNADE et al, 2018).

Climate is the main factor responsible for the appearance and development of molds and implicitly for the presence of mycotoxins in plants. Dry and hot climate promotes the process of fungal growth and aflatoxin production. The most important mycotoxin is aflatoxin B1 (AfB1), due to its abundance and linkage to serious health effects (BERTHILLER et al, 2017). In the developing world, particularly among small scale and subsistence farmers, the actual health challenges posed by mycotoxin exposure continue to be a great problem.

Addressing these issues requires innovative approaches, in which analytical science must also play an essential part by offering appropriate analytical methods outside the laboratory (BERTHILLER et al, 2017). Due to several variables, including the distribution of mycotoxins in multiple foods, accessible analytical techniques and toxicological information, and the readiness of public organizations (FAO, 2004), the establishment of legal limits regarding the presence of mycotoxin in meat and feed has been a complicated task. More than 100 nations have already set limits for mycotoxins occurrence in food and feed. However, other nations, particularly developing countries, do not have clear laws. In addition, allowable AFM1 limits also differ from nation to nation in dairy products. In dairy cattle, aflatoxins are the most intensively researched mycotoxins since the excretion of aflatoxin M1 in milk is of public health concern. The mycotoxin is absorbed along with the rest of the digestive tract by passive diffusion and then hydroxylated in the liver to aflatoxin M1 (KUILMAN et al, 2010; MATABARO E. et al, 2012). Concerns over the adverse health and financial effect of mycotoxins have motivated the research for methods aiming at preventing the development of toxins in food and eliminating, inactivating or reducing their bioavailability in contaminated products (GONCALVES et al, 2016).

Current ultrasensitive detection methods for ATM1 are primarily based on thin-layer chromatography (TLC), high-performance fluid chromatography (HPLC) or UV light spectroscopy after extraction and clean-up procedures. In spite the fact that these techniques are adequately delicate and precise, they often require advanced, costly and heavy equipment's that may not be accessible in low-resource laboratories, particularly not being suitable for mass screening (HANSMANN et al, 2009). Therefore, there is a need for the rapid development and application of fast, cheap, portable and sensitive methods for the detection of mycotoxins in agriculture and the food industry. This study presents some innovative, fast methods for the identification of mycotoxins, as well as methods of decontamination or prevention of mycotoxin occurrence in feed and milk.

\section{Innovative techniques for determining mycotoxins from feed and milk cow}

The presence of high levels of AFM1 poses an alarming threat because dairy products contain essential nutrients for human health, especially for children and infants.

Therefore, a quick and reliable screening method is urgently needed to detect trace aflatoxins in food. Several analytical methods have been used for the detection of aflatoxin based on high-performance liquid chromatography (HPLC) and mass spectroscopy; however, they are costly, time consuming and require a lot of skills (KARLOVSKY et al, 2016). These research techniques are supposed to be carried out at the testing site, outside the laboratory. Results are expected to be obtained in a short time, either with the aid of simple portable devices or without using any devices or readers. In addition to standard ELISA procedures, there are many forms of rapid visual immunoassay strips available for on-site mycotoxin screening (MARAGOS and BUSMAN, 2010; PEREIRA et al, 2014).

\section{Lateral Flow (LFD)}

Over the past years, a growing interest was observed in developing rapid field test strips to classify important food pollutants such as foodborne pathogens, veterinary pharmaceutical residues, pesticides, allergens and mycotoxins (ALSHANNAQ and YU, 2017).

These test techniques are intended to be carried out at the inspection site, outside the laboratory. Results are anticipated to be obtained in a short time, either with the assistance of easy portable devices or without using any devices or readers. In addition to popular ELISA processes, there are many types of fast visual immunoassay strips available for on-site mycotoxin testing, including lateral flow, dipstick, and flow-through devices (PEREIRA et al, 2014; MARAGOS and BUSMAN 2010). Lateral flow 
was created as a single-stage experiment that involves a negative control line on the same strip alongside the sample rows. A lateral flow test can yield semi-quantitative outcomes in less than 10 minutes and does not require any special facilities. LFDs are accessible commercially for AF, DON, T-2 toxin, OTA and ZEA detection. However, in relation with their high price, their field applications are restricted owing to various sensitivity and reliability issues in distinct matrices (ALSHANNAQ and YU, 2017).

2. Microfluidic "lab-on - a chip" devices may integrate and miniaturize versatile functions, from sample preparation to detection, demonstrating great potential for rapid, accurate and high-performance mycotoxin detection (LUJIA et al, 2015).

Immunoassays are simple, fast, sensitive, portable and cost effective compared to other common methods. Most of them may even be applied to monitoring on site while maintaining their specificity and high sensitivity. However, due to many factors such as low antibodies specificity to antigens or matrix, and poor color change, these methods may present some limitations.

In addition, future immunoassays for AFM1 in both developed and developing countries should be rapid, lowcost and accessible.

Because crops may be contaminated at any stage of processing, a coordinated-on site monitoring and evaluation of AFs is also urgently needed. However, this requires exploring new advances in food biotechnology and agricultural science that will not only ensure effective control of AFM1 in feed and food, but also prevent Aspergillus from spreading on crops (MATABARO E., 2017).

3. Dipstick analysis operates similar to ELISA and involves planning and incubation steps to achieve results that usually take more than 30 minutes. Dipsticks are available commercially to detect single contamination of mycotoxins in food. The first dipstick test was developed to detect FB1 in maize-based foods with a visual limit of 40-60 ng / g. Nonetheless, a multi-analyte dipstick immunoassay has been developed to detect different mycotoxins, but its sensitivity is reduced (GORYACHEVA et al, 2007; KRSKA et al, 2009). A multiplex immunoassay dipstick was also used to detect major Fusarium toxins including ZEA, T-2, and HT-2 toxins, DON and fumonisins in rice, barley, and maize (LATTANZIO et al, 2012), DON and ZEA in wheat, and ZEA and OTA in maize.

With the latest developments in science and technology, new techniques may now detect and trace mycotoxins in food and feed, but resource constraints restrict their accessibility in developing nations. Among the mycotoxins, aflatoxins are highly toxic and carcinogenic contaminants that affect the safety of many foods and thus put human health at risk. Aflatoxin M1 (AFM1) has been found to be the result of aflatoxin B1 biotransformation in milk (ALSHANNAQ and YU, 2017).

Much effort has been made to monitor the source of AFM1 from farmers to dairy product firms. Immunoassay methods, including enzyme-linked immunosorbent assay (ELISA), immunosensors, and lateral immunoassay (LFIA), were recently preferred for food analysis due to improved qualities such as high sensitivity, simplicity, and on-site monitoring. AFM1 however escapes ordinary methods of food treatment such as cooking, sterilization and freezing, thereby appearing in dairy products.

4. Fourier Transform mid infrared spectroscopy optical methods that integrate infrared (IR) analyzers coupled with main component analysis (PCA) to monitor and quantify mycotoxins without sample preparation promise fast and non-destructive techniques for the detection of mycotoxins in cereals (PETTERSSON et al, 2003; HOSSAIN and GOTO, 2014). For the detection of DON contamination in wheat and maize, both near-IR reflectance spectroscopy and mid-IR infrared transmission spectroscopy were used (BERARDO et al, 2005; De GIROLAMO et al, 2009; KOS et al, 2003). For on-site analysis of DON and AFB1 samples from maize, wheat and peanuts, a portable IR laser spectroscopy device was recently developed (PETTERSSON et al, 2003; SIEGER et al, 2017).

However, further work is required to investigate the full potential of IR spectroscopy in detecting specific mycotoxins, as both methods face challenges such as uneven distribution of mycotoxins within the food matrix, particle size of and detection limits (ALSHANNAQ and YU, 2017).

These approaches enable sample preparation to be reduced to an absolute minimum and integrated into online surveillance systems. Nevertheless, since the output of the chemical analysis is based on rapid data interpretation, the high dependence of the matrix and the lack of adequate calibration materials are still major constraints. Based on the same principles, with a range of electronic chemical sensors with pattern recognition systems, electronic noses were also developed (LOGRIECO et al, 2005).

4.1. Electronic noses - An electronic nose is a variant of gas chromatography that imitates the sensory olfactory system of humans and provides a non-destructive, rapid and low-cost analysis of mycotoxins in food samples (KESHRI and MAGAN, 2000). Current applications of electronic nose for mycotoxin detection more have focused on the detection of toxigenic fungi than detecting the mycotoxin. Studies on the use of electronic noses for maize AF detection and grain DON have been published (CAMPAGNOLI et al, 2009; OLSSON et al, 2002). Using this technique to analyze the mycotoxins in food is still in the early stage of development. To measure the low levels of mycotoxins in food samples, instrumentation needs to be optimized. Future trends in screening methods include the further development of quick and simple tests, with improved detection capabilities for simultaneous measurement of multiple mycotoxins.

\section{Decontamination and prevention strate- gies for mycotoxins in the diet of dairy cows}

There are multiple possible causes of fungal infection, therefore fungal and mycotoxin prevention strategies must be implemented at an integrative level throughout the food production chain (plant growth, processing, storage and distribution).

The intervention should occur before any fungal infestation or during the plant material and mycotoxin production mold invasion, when the agricultural products have been identified as highly contaminated (JOUANY, 2007). 
Because mycotoxins cause serious diseases in farm animals, the EU has approved the use of mycotoxin detoxifying agents by including a new group of feed additives identified as 'substances capable of suppressing or reducing absorption, promoting mycotoxin excretion or altering their mode of action' (EC, 2009).

At the same time, the European Food Safety Agency (EFSA) published a study on mycotoxin detoxifying agents used as feed additives (BOUDERGUE et al, 2009), covering issues such as mode of action, efficacy and food safety. Also, a serious concern for human health is the contamination of mycotoxin from dairy cattle diets, as some mycotoxin metabolites, especially aflatoxin M1, may be excreted in milk. Effective agricultural practices, antimicrobials, genetic engineering and storage control will avoid contamination.

Methods of decontamination for Aflatoxin M1 in milk using microbial adsorbents has received a lot of attention, since this mycotoxin has a significant impact on human and animal health. Furthermore, numerous studies have examined the ability for different microbial agents to bind AFM1 (ASSAF et al, 2019). For the removal or inactivation of mycotoxin, physical, chemical and biological methods may be used (CORASSIN et al, 2013). Entero-adsorption is used by adding compounds that are nutritionally inert to the diet in order to reduce bioavailability. These compounds may sequester and prevent absorption of mycotoxins in the gastrointestinal tract of animals (De OLIVEIRA and CORASSIN, 2014).

\section{Microbial Biofilm}

A 2019 study by Assaf et al showed a prospective alternative into retaining microbial agents used to decontaminate AFM1 in milk, by using a biofilm able to significantly remove AFM1 from contaminated whole milk (up to $60.74 \%$ ).

In addition, other authors showed that the content of milk protein was not modified after passing contaminated milk through or over a special designed biofilm for AFM1binding (GU et al, 2014). Concerns about the negative health and economic impact of mycotoxins have led to research into strategies to prevent the production of toxins in food and to eliminate, inactivate or reduce their bioavailability in contaminated products (GONCALVES et al, 2015). Thermal inactivation, ultraviolet light, ionizing radiation or solvent extraction are the major physical methods used to inactivate mycotoxin.

Chemical methods include chlorination and hydrolytic or oxidant agents. However, both chemical and physical methods have advantages and disadvantages, since they do not completely remove the toxin, are expensive and cause the products nutritional and organoleptic losses (De OLIVEIRA et al, 2014).

Biological methods are focused on the action of micro-organisms such as yeasts, molds, bacteria and algae on mycotoxins through competition of nutrients and space, interaction and antibiotics. The use of microorganisms is an attractive alternative in food and animal feed for controlling and eliminating aflatoxins, protecting their quality and safety.

One of the most effective adsorbent types used to decontaminate AFM1 is microbial. These methods are based on the use of various bio adsorbent agents such as bacteria and yeasts in milk for complex AFM1 removal.
The decontamination methods' efficiency was thus addressed and plausible experimental variants were discussed (ASSAF et al, 2019).

Consumer Product Safety - This method implies the use of several probiotics that are "Generally Recognized as Safe" (GRAS) microorganisms for AFM1 dairy detoxification. It should be noted that probiotics, including customers of dairy products, may have positive impacts on the host (SÁNCHEZ et al, 2017). Due to the partial reversibility of this form of binding, it is difficult to estimate the amount of adsorbents required. In addition, the stability of AF binding in milk or other liquids may vary, depending on distinct environmental conditions, including storage moment, $\mathrm{pH}$, milk temperature and concentration of the microbial adsorbents used (MARREZ et al, 2018).

\section{Microbial Fixation on Support or Membrane}

The suggested technique reported by Foroughi et al in 2018 is to detoxify AFM1 - contaminated milk by immobilizing yeast such as Saccharomyces cerevisiae. The findings showed a significant reduction in concentration of AFM1 for all milk samples, screened with different original content of AFM1. The largest decrease of AFM1, respectively $81.3 \%$, was achieved after 80 minutes of milk flowing in the biofilter. This research disclosed the elevated capacity of immobilized yeast cells to detoxify AFM1 without any physicochemical modifications (FOROUGHI et al, 2018).

These promising findings may be used for additional studies, such as fixing efficient amounts of yeasts or mixtures on a support or membrane that may be used to detoxify AFM1 by passing through or above contaminated liquids. Customized biofilters or cartridges containing these biological adsorbents may be more appropriate for industrial use.

\section{Zeolites}

The recent trends in the elimination of mycotoxin from food and feed have led to the use as nutritional additives of various adsorbents. Because of their opposite polarity, the most commonly used are clay particles such as bentonites and zeolites (DAL POZZO et al, 2016).

The drawback of clay absorbers is their ability to bind to minerals and vitamins from feed. For this reason, it is necessary to increase the dietary content of micronutrients by an average of $20 \%$. However, the efficacy of mycotoxin absorbers varies between $20 \%$ and $80 \%$ (HORKY et al, 2018).

Clinoptilolite and other zeolite' capacity to absorb aflatoxins that contaminate feed and improve the health of various farm anima has led to their use in this area. There are countless reviews regarding mycotoxin binders presenting the advantages and the adsorption ability of the zeolites (AVANTAGGIATO et al, 2005).

In the event of mycotoxicosis, zeolites may bind polar toxins such as aflatoxins, a feature confirmed in many researches, despite the reality that the findings are often contradictory.

The use of aluminium-binding agents such as zeolites, montmorillonite and bentonite clays has become common practice in the feed and food industries with the aim of effectively adsorbing mycotoxin (KABAK et al, 2006). Notwithstanding their spread use and the possible benefits, they are considered to have restricted efficacy against zearalenone, ochratoxin and trichothecenes (EROGLU et al, 2017). 


\section{Graphene}

Graphene is a two-dimensional (2D) carbon nanomaterial, discovered in 2004, with a high adsorption capacity, mainly due to its exceptional thermal and mechanical properties, good chemical stability, high surface area and excellent electrical conductivity (HUANG et al, 2011; JIANG et al, 2018; NOVOSELOV et al, 2004).

One of the most promising methods for mycotoxin absorption is the use of carbon-based nanomaterials. Graphene has been shown to have a huge surface and high binding capacity for mycotoxins (PIROUZ et al, 2017).

Graphene oxidation and the introduction of certain metal nanoparticles, new synthesized materials have been successfully applied in the identification of metallic ions, sulfonamides, colorants, pesticides and aflatoxins, proving to be novel efficient sample preparation adsorbents (JIANG et al, 2018).

Graphene oxide and gold nanoparticles (rGO / $\mathrm{Au}$ ) composite were synthesized and used as sorbents for the concurrent purification and enrichment of AFB1, AFM1, OTA, ZEA, $\alpha$-ZOL, $\beta$-ZOL, ZAN, $\alpha$-ZAL and $\beta$-ZAL in milk, subsequently confirmed by UHPLC MS / MS technique (JIANG et al, 2018; PIROUZ et al, 2017).

\section{Green-synthetized nanoparticles}

Because there is no efficient antidote, nutritional supplements may suppress mycotoxin's toxic effect, reduce tissue damage induced by oxidative stress, and enable the body to maintain a sustainable immune system that can eradicate the pathogen (HOU et al, 2013).

Green-synthetized nanoparticles are well known to be enriched with natural compounds, leading to better donor activity (RAVEENDRAN et al, 2003). Although their efficacy against mycotoxin poisoning has not yet been investigated, it should be presumed that they have positive effects on organisms (PONZILACQUA et al, 2018).

There are predominantly studies focusing on synthesis of nanoparticles. Large-scale production has been improved by comparing the prices of nanoparticles with those of commonly used bentonite for the removal of mycotoxins from feeding stuffs. Theoretically, to remove the toxic effect, only $30 \mathrm{mg}$ of nanoparticles per $1 \mathrm{~kg}$ of compound feed are necessary. From the literature, we find that in the case of the toxicity of selected nanoparticles, the safe level for mice is on average $0.3-16.000 \mathrm{mg} / \mathrm{kg}$. Taken together, the results of nano adsorbent efficacy against mycotoxins would have been far more compelling if the researchers had found the actual practical feed dose of mycotoxins (HORKY et al, 2018).

\section{Chitosan Polymeric Nanoparticles}

Chitosan is a natural chitin-based cationic polysaccharide, the structural component found in the crustacean exoskeleton. Chitosan has low immunogenicity, biodegradable and is non-toxic. Chitosan has therefore shown promising results from various raw materials for the removal of mycotoxin. In the 1990, chitosan started to be regarded as an effective mycotoxin adsorbent with an efficacy of approximately 70\% (KHAJARERN et al, 2003). However, a chitosan solution was patented in a mixture with the minerals rektorit and attapulgit to extract feed zearalenone and reduce diarrhea due to its antimicrobial properties. While carbon nanostructures are the subject of much research nowadays, in the period 2010-2015 chitosan polymer and nanoparticles were also intensively investigated (HORKY et al, 2018). It is widely known that specific compounds may be encapsulated by CS NPs. Glutaraldehyde crosslinked chitosan showed promising adsorption ability for AFL B1 (73\%), OTA (97\%), ZEN (94\%), and FUM1 (99\%) but no obvious adsorption for DON and T2 $(<30 \%)$ in a buffer system simulating gastrointestinal conditions (ZHAO et al, 2015; HORKY et al, 2018). Therefore, the use of adsorbents as feed additives is the only practical solution to feed decontamination, although it should be widely studied in order to guarantee their effectiveness and safety, according to the current demands of farmers (VILA-DONAT et al, 2018).

\section{Economic impact}

The economic consequences of mycotoxin pollution are very important, and it is often necessary to destroy crops with large amounts of mycotoxin (VILA-DONAT et al, 2018). Cereals such as wheat, corn, barley, rye and oat are the most vulnerable crops to mycotoxin exposure (RODRÍGUEZCARRASCO et al, 2013; VIDAL et al, 2013).

These small chemicals pose an open challenge to food safety and serious risk to human and animal health, contributing to the massive economic losses of the agricultural industry.

Huge efforts have been made to control or minimize the occurrence of mycotoxin in foods from around the world, but there is still a problem with food contamination with mycotoxin (ALSHANNAQ and YU, 2017). The presence of mycotoxins in food is causing serious health problems for consumers and is affecting the food industry economically (MATABARO et al, 2017).

Mycotoxins have a significant financial and commercial impact on the production and nutritional value of contaminated cereals and forage (RATCLIFF, 2002). The main financial losses are synonymous with the effect on human health, animal productivity, and domestic and foreign trade. It is estimated that $25 \%$ of food plants in the world are infected by mycotoxin-producing fungi, including many essential foods. According to FAO estimates, global food losses from mycotoxins are estimated at 1,000 million tons per year (IHESHIULOR et al, 2011).

Collaborative and ongoing efforts by government, academia and industry are needed to control mycotoxin production in the field, inhibit the growth of toxic molds in food and feed, and improve detection techniques to improve food safety (ALSHANNAQ and YU, 2017).

\section{Conclusion}

Mycotoxins research's is continuing to progress scientifically of new technique emerges. Many other promising new approaches for evaluating mycotoxins in food have been suggested, but these methods need further testing. Food industry needs concerted and ongoing efforts to monitor the production of mycotoxin in the field, inhibit toxic mold growth in food and feed, and develop rapid and cost-effective detection techniques to improve food safety.

As recommendations for farmers, the following points should be forwarded: 
- Further study should be undertaken on the occurrence economic and public health significance of mycotoxins;

- Owners or farmers should be aware of the effects and sources of mycotoxins;

- A good Information of the farmers on the application of the fast methods for the identification of mycotoxins in feed and milk;

- Application in small farms of strategies for decontamination of mycotoxin-infected feed and milk.

\section{References}

1. ALSHANNAQ A, YU JH, Occurrence, Toxicity, and Analysis of Major Mycotoxins in Food. Int. J. Environ. ResPublic Health. 2017; 14(6): 632.

2. ASSAF JC, KHOURY A, CHOKR A, LOUKA et al. A novel method for elimination of aflatoxin M1 in milk using Lactobacillus rhamnosus GG biofilm. Dairy Technol. 2019; 70:1-9, doi: 10.1111/1471-0307.12578

3. ASSAF JC, NAHLE S, CHOKR A, LOUKA N, ATOUI A, KHOURY AE, Assorted Methods for Decontamination of Aflatoxin M1 in Milk Using Microbial Adsorbents. Toxins, 2019; 11, 304

4. AVANTAGGIATO G, SOLFRIZZO M, VISCONTI A, Recent advances on the use of adsorbent materials for detoxification of Fusarium mycotoxins. Food Addit Contam. 2005; 22(4):379-88.

5. BECKER-ALGERI TA, CASTAGNARO D, De BORTOLI K, De SOUZA C et al. Mycotoxins in Bovine Milk and Dairy Products: A Review. J Food Sci. 2016; 81(3): R544-52. doi: 10.1111/1750-3841.13204

6. BERARDO N, PISACANE V, BATTILANI P, SCANDOLARA A et al. Rapid detection of kernel rots and mycotoxins in maize by near-infrared reflectance spectroscopy. J. Agric. Food Chem. 2005; 53:8128-8134.

7. BERTHILLER F, CRAMER B, IHA MH, KRSKA R et al. Developments in mycotoxin analysis: an update for 2016-2017. World Mycotoxin J, 2017; DOI 10.3920/ WMJ2017.2250

8. BHAT R, RAI RV, KARIM AA, Mycotoxins in Food and Feed: Present Status and Future Concerns. Compr. Rev. Food Sci. Food Saf, 2010; 9, 57-81.

9. BOUDERGUE C, BUREL C, DRAGACCI S, FAVROT $\mathrm{MC}$ et al. Review of mycotoxin-detoxifying agents used as feed additives: mode of action, efficacy and feed/food safety. External Scientific Report Submitted to EFSA, 2009; https://www.efsa.europa.eu/en/supporting/pub/en22 (Accessed on December 2017).

10. CAMPAGNOLI A, CHELI F, SAVOINI G, CROTTI A, et al. Application of an electronic nose to detection of aflatoxins in corn. Vet. Res. Commun. 2009; 33 (Suppl. 1), 273-275.

11. CORASSIN $\mathrm{CH}$, BOVO F, ROSIM RE, OLIVEIRA CAF, Efficiency of Saccharomyces cerevisiae and lactic acid bacteria strains to bind aflatoxin M1 in UHT skim milk C.H. Food Control. 2013; 31:80-83. doi: 10.1016/ j.foodcont.2012.09.033

12. DAL POZZO M, VIEGAS J, KOZLOSKI GV, STEFANELLO CM et al. The effect of mycotoxins adsorbents beta glucans or montmorillonite on bovine ruminal fermentation in vitro. Acta Sci. Vet. 2016; 44, 6.

13. DE GIROLAMO A, LIPPOLIS V, NORDKVIST E, VISCONTI A, Rapid and non-invasive analysis of deoxynivalenol in durum and common wheat by FourierTransform Near Infrared (FT-NIR) spectroscopy. Food Addit. Contam. Part A. 2009; 26:907-917.
14. De OLIVEIRA CA, CORASSIN $\mathrm{CH}$, Aflatoxins. Mycotoxins and Their Implications in Food Safety, Chapter 1, 6-19, 2014.

15. DESAI KGH, Chitosan nanoparticles prepared by ionotropic gelation: An overview of recent advances. Crit. Rev. Ther. Drug Carrier Syst. 2016; 33, 107-158.

16. DRIEHUIS F, SPANJER MC, SCHOLTEN JM, GIFFEL $\mathrm{MC}$, Occurrence of mycotoxins in feedstuffs of dairy cows and estimation of total dietary intakes. J. Dairy Sci. 2008; 91 pp. 4261-4271.

17. EC, 2009 - European Commission. Commission Regulation (EC) No. 386/2009 of 12 May 2009 amending Regulation (EC) No. 1831/2003 of the European Parliament and of the Council as regards the establishment of a new functional group of feed additives. Off. J. EU. L 118, 66.

18. EROGLU N, EMEKCI M, ATHANASSIOU CG, Applications of natural zeolites on agriculture and food production. J Sci Food Agric, 2017; 97(11), 3487-3499. doi: $10.1002 /$ jsfa. 8312

19. FAO, 2004. Food and Agriculture Organization of the United Nations. Worldwide regulations for mycotoxins in food and feed. Available at: http://www.fao.org/ tempref/docrep/fao/007/y5499e/y5499e00.pdf (Accessed on December 2019).

20. FOROUGHI M, SARABI JAMAB M, KERAMAT J, FOROUGHI M, Immobilization of Saccharomyces cerevisiae on Perlite Beads for the Decontamination of Aflatoxin M1 in Milk. J. Food Sci. 2018; 83:2008-2013. doi: 10.1111/1750-3841.14100

21. GONÇALVES BL, CORASSIN CH, OLIVEIRA CAF, Mycotoxicoses in Dairy Cattle: A Review. Asian J Anim Vet Adv, 2015; 10 (11): 752-760.

22. GONÇALVES RA, NAEHRER K, SANTOS GA, Occurrence of mycotoxins in commercial aquafeeds in Asia and Europe: a real risk to aquaculture? Rev Aquacult, 2016; 10(2), 263-280, doi:10.1111/raq.12159.

23. GORYACHEVA IY, DE SAEGER S, EREMIN SA, VAN PETEGHEM C, Immunochemical methods for rapid mycotoxin detection: Evolution from single to multiple analyte screening: A review. Food Addit. Contam. 2007; 24, 1169-1183.

24. GU H, REN D, Materials and surface engineering to control bacterial adhesion and biofilm formation: A review of recent advances. Front. Chem. Sci. Eng. 2014; 8:20-33. doi: 10.1007/s11705-014-1412-3

25. HANSMANN T, SANSON B, STOJAN J, WEIK M et al. Kinetic insight into the mechanism of cholinesterasterase inhibition by aflatoxin B1 to develop biosensors. Biosens Bioelectron, 2009; 24:2119-2124.

26. HORKY P, SKALICKOVA S, BAHOLET D, SKLADANKA J, Nanoparticles as a Solution for Eliminating the Risk of Mycotoxins. Nanomaterials, 2018; 8, 727; doi:10.3390/nano8090727

27. HORKY P, SKALICKOVA S, BAHOLET D, SKLADANKA J, Nanoparticles as a Solution for Eliminating the Riskof Mycotoxins. Nanomaterials, 2018; 8, 727 .

28. HOSSAIN MZ, GOTO T, Near- and mid-infrared spectroscopy as efficient tools for detection of fungal and mycotoxin contamination in agricultural commodities. World Mycotoxin J, Special Issue: Rapid methods for mycotoxin detection, 2014; 7 (4): 507-515.

29. HOU YJ, ZHAO YY, XIONG B, CUI XS, KIM NH et al. Mycotoxin-containing diet causes oxidative stress in the mouse. PLoS ONE, 2013; 8, e60374. 
30. HUANG X, YIN Z, WU S, QI X et al. Graphene-based materials: Synthesis, characterization, properties, and applications. Small, 2011; 7(14), 1876-1902.

31. IHESHIULOR OOM, ESONU BO, CHUWUKA OK, OMEDE AA et al. Effects of Mycotoxins in Animal Nutrition: A Review. Asian J. Anim. Sci. 2011; 5, 1 19-33.

32. JIANGA K, HUANGA Q, FANB K, WUC L et al. Reduced graphene oxide and gold nanoparticle compositebased solid-phase extraction coupled with ultra-highperformance liquid chromatography tandem mass spectrometry for the determination of 9 mycotoxins in milk. Food Chem. 2018; 264, 218-225.

33. JOUANY JP, Methods for preventing, decontaminating and minimizing the toxicity of mycotoxins in feeds. Anim. Feed Sci. Technol. 2007;137, 342-362.

34. KABAK B, DOBSON AD, Var I, Strategies to prevent mycotoxin contamination of food and animal feed: a review. Crit Rev Food Sci Nutr, 2006; 46:593-619.

35. KARLOVSKY P, SUMAN M, BERTHILLER F, De MEESTER $J$ et al. Impact of food processing and detoxification treatments on mycotoxin contamination. Mycotoxin Res, 2016; DOI 10.1007/s12550-016-0257-7

36. KESHRI G, MAGAN N, Detection and differentiation between mycotoxigenic and non-mycotoxigenic strains of two Fusarium spp. using volatile production profiles and hydrolytic enzymes. J. Appl. Microbiol. 2000; 89, 825-833.

37. KHAJARERN JM, KHAJARERN S, MOON TH, LEE $\mathrm{JH}$, Effects of dietary supplementation of fermented chitin-chitosan (fermkit) on toxicity of mycotoxin in ducks. Asian-Australas. J. Anim. Sci. 2003; 16, 706-713.

38. KOS G, LOHNINGER H, KRSKA R, Development of a method for the determination of Fusarium fungi on corn using mid-infrared spectroscopy with attenuated total reflection and chemometrics. Anal. Chem. 2003; 75:1211-1217.

39. KRSKA R, MOLINELLI A, Rapid test strips for analysis of mycotoxins in food and feed. Anal. Bioanal. Chem. 2009; 393, 67-71.

40. KUILMAN T, MICHALOGLOU C, MOOI WJ, PEEPER DS, The essence of senescence. Genes Dev. 2010; 15;24(22):2463-79. doi: 10.1101/gad.1971610

41. LATTANZIO VM, NIVARLET N, LIPPOLIS V, DELLA GATTA $S$ et al. Multiplex dipstick immunoassay for semi-quantitative determination of Fusarium mycotoxins in cereals. Anal. Chim. Acta, 2012; 718, 99-108.

42. LOGRIECO A, ARRIGAN DWM, BRENGEL-PESCE $\mathrm{K}$, SICILIANO $\mathrm{P}$ et al. DNA arrays, electronic noses and tongues, biosensors and receptors for rapid detection of toxigenic fungi and mycotoxins: A review. Food Addit Contam A, 2005; 22(4): 335-344.

43. LUJIA G, JINSONG $F$, ZECONG F, JIE $X$ et al, Application of microfluidic "lab-on-a-chip" for the detection of mycotoxins in foods. Trends Food Sci Tech, 2015; 46, 252-263.

44. MARAGOS CM, BUSMAN M, Rapid and advanced tools for mycotoxin analysis: A review. Food Addit. Contam. Part A, 2010; 27, 688-700.

45. MARREZ DA, SHAHY EM, EL-SAYED HS, SULTAN YY, Detoxification of Aflatoxin B1 in milk using lactic acid bacteria. J. Biol. Sci. 2018; 18:144-151. doi: 10.3923/ jbs.2018144.151

46. MATABARO E, ISHIMWE N, UWIMBABAZI E, LEE BH, Current Immunoassay Methods for the Rapid Detection of Aflatoxin in Milk and Dairy Products, COMPR REV FOOD SCI F, 2017; 16, p. 808-820.

47. MATABARO E, ISHIMWE N, UWIMBABAZI E, LEE $\mathrm{BH}$, Current Immunoassay Methods for the Rapid Detection of Aflatoxin in Milk and Dairy Products. WORLD MYCOTOXIN J, 2012; 5 (1): 3-30.

48. NJUMBE EE, VAN POUCKE C, DE SAEGER S, A multi-analyte LC-MS/MS method for the analysis of 23 mycotoxins in different sorghum varieties: The forgotten sample matrix. Food Chem., 2015; 177, 397-404.

49. NOVOSELOV KS, GEIM AK, MOROZOV SV, JIANG $D$ et al. Electric field effect in atomically thin carbon films. Science, 2004; 306(5696), 666-669.

50. OGUNADE IM, JIANG Y, KIM DH, PECH CERVANTES AA et al. Fate of Escherichia coli O157:H7 and bacterial di-versity in corn silage contaminated with the pathogen and treated with chemical or microbial additives, J. Dairy Sci. 2017; 100:1780-1794.

51. OGUNADE IM, TUPPIA MC, QUEIROZ OCM, JIANG $\mathrm{Y}$ et al. Silage review: Mycotoxins in silage: Occurrence, effects, prevention, and mitigation. J Dairy Sci, 2018; 101, 5, 4034-4059.

52. OLSSON J, BÖRJESSON T, LUNDSTEDT T, SCHNÜRER J, Detection and quantification of ochratoxin $\mathrm{A}$ and deoxynivalenol in barley grains by GC-MS and electronic nose. Int. J. Food Microbiol. 2002; 72, 203-214.

53. PEREIRA VL, FERNANDES JO, CUNHA SC, Mycotoxins in cereals and related foodstuffs: A review on occurrence and recent methods of analysis. Trends Food Sci. Technol. 2014; 36, 96-136.

54. PETTERSSON H, ABERG L, Near infrared spectroscopy for determination of mycotoxins in cereals. Food Control, 2003; 14 229-232.

55. PIROUZ AA, SELAMAT J, IQBAL SZ, MIRHOSSEINI $\mathrm{H}$ et al The use of innovative and efficient nanocomposite (magnetic graphene oxide) for the reduction on of Fusarium mycotoxins in palm kernel cake. Sci. Rep, 2017; 7(1). doi:10.1038/s41598-017-12341-3

56. PONZILACQUA B, CORASSIN CH, OLIVEIRA CAF, Antifungal Activity and Detoxification of Aflatoxins by Plant Extracts: Potential for Food Applications. Open Food Sci J, 2018; 10, 24-32, 10.2174/1874256401810010024

57. RATCLIFF J, 2002. The Role of Mycotoxins in Food and Feed Safety. Animal Feed Manufacturers Association, South Africa.

58. RAVEENDRAN P, FU J, WALLEN SL, Completely "green" synthesis and stabilization of metal nanoparticles. J. Am. Chem. Soc. 2003; 125, 13940-13941.

59. RODRÍGUEZ-CARRASCO Y, RUIZ MJ, FONT G, BERRADA H, Exposure estimates to Fusarium mycotoxins through cereals intake. Chemosphere. 2013; 93, 2297-2303.

60. SÁNCHEZ B, DELGADO S, BLANCO-MÍGUEZ A, LOURENCO A et al. Probiotics, gut microbiota, and their influence on host health and disease. Mol. Nutr. Food Res. 2017; 61:1-15. doi: 10.1002/mnfr.201600240

61. SIEGER M, KOS G, SULYOK M, GODEJOHANN M et al. Portable infrared laser spectroscopy for on-site mycotoxin analysis. Sci. Rep. 2007; 7:44028.

62. SKALICKOVA S, MILOSAVLJEVIC, CIHALOVA K, HORKY P et al. Selenium nanoparticles as a nutritional supplement. Nutrition, 2017; 33, 83-90.

63. VIDAL A, MARÍN S, RAMOS AJ, CANO-SANCHO G et al. Determination of aflatoxins, deoxynivalenol, ochratoxin A and zearalenone in wheat and oat-based bran supplements sold in the Spanish market. Food Chem. Toxicol. 2013; 53, 133-138.

64. VILA-DONAT P, MARIN S, SANCHIS V, RAMOS AJ, A review of the mycotoxin adsorbing agents, with an emphasis on their multi-binding capacity, for animal feed decontamination. Food Chem Toxicol, 2018; 114, pp. 246-259, 10.1016/j.fct.2018.02.044

65. WOMACK ED, SPARKS DL, BROWN AE, Aflatoxin M1 in milk and milk products: a short review. World Mycotoxin J, 2016; 9 (2): 305-315.

66. ZHAO Z, LIU N, YANG L, WANG J et al. Cross-linked chitosan polymers as generic adsorbents for simultaneous adsorption of multiple mycotoxins. Food Control, 2015; 57, 362-369. 